\title{
STRUKTUR KOMUNITAS MAKROZOOBENTOS DAN KONDISi PERAIRAN DASAR DI PANTAI TIMUR SUMATERA UTARA
}

\author{
Suprapto"), Bambang Sumiono", dan Nardi Hendriyatna")
}

\begin{abstract}
ABSTRAK
Penelitian telah dilakukan pada bulan September 2003 di wilayah perairan pantai timur Propinsi Sumatera Utara (Selat Malaka) dengan metode pengambilan sampel pada 12 stasiun. Tujuan penelitian adalah untuk mendapatkan informasi struktur komunitas makrozoobentos meliputi komposisi jenis, kepadatan, dan indeks keragaman hayati bentos serta kondisi lingkungan perairan dasar yang meliputi parameter suhu, salinitas, arus, dan tipe sedimen. Pengambilan sampel substrat dilakukan secara acak terpilih menggunakan Grab Bottom Sampler, ukuran $20 \times 20 \mathrm{~cm}$. Hasil penelitian menunjukkan bahwa, jenis makrozoobentos yang teridentifikasi terdiri atas 36 jenis yang didominasi oleh Filum Moluska, sedangkan lainnya tergolong dalam Filun Annelida, Arthropoda, dan Echinodermata. Kepadatannya berkisar $3,8 \times 10^{3}-7,1 \times 10^{5}$ ind $\mathrm{m}^{-2}$. Keragaman jenis makrozoobentos relatif rendah dengan nilai indeks keragaman $\left(\mathrm{H}^{\prime}\right)$ rata-rata 1,77 dan termasuk kategori perairan tercemar. Kelimpahan relatif di antara jenis cenderung merata dengan nilai indeks kemerataan $(E)=0,77$. Makrozoobentos yang paling melimpah adalah Tellina sp., Epicodakia sp., Dentalium sp., Turitella $\mathrm{sp}$., dan Plicarcularia sp. Kondisi suhu dan salinitas relatif merata dengan nilai rata-rata $29,13^{\circ} \mathrm{C}$ dan $32,83 \%$. Kecepatan arus umumnya lemah berkisar $0,05-0,53 \mathrm{~m} \mathrm{dt}^{-1}$, sedangkan substrat dasar didominasi oleh campuran tekstur pasir dan lumpur.
\end{abstract}

AESTRACT: Community structure of macrozoobenthos in Easthern Sumatera Utara Waters. By: Suprapto, Bambang Sumiono, and Nardi Hendriyatna

Study on community structure of macrozoobenthos was conducted in Province Sumatera Utara waters (Malaka Strait) at September 2003 by sampling in selected twelve stations. Sampling of substrates was conducted by using Grab Bottom Sampler. The objective of the study is to gather information on species composition, density, diversity indexes and some parameters of bottom water quality. Results show that the number of species of macrozoobentos collected were 36 species of phylum Mollusca, Annelida, Arthropoda, and Echinodermata. Diversity of total macrozoobentos varied from $3,8 \times 10^{3}-7,1 \times 10^{5}$ ind $\mathrm{m}^{-2}$. Diversity index is low-grade $\left(H^{\prime}=1.77\right)$ its indicating a polluted condition. Average level of evenness indexces was 0.77 . The most abundances of macrozoobentos species were Tellina sp., Epicodakia sp., Dentalium sp., Turitella sp., and Plicarcularia sp. The average levels of temperature and salinity were $29.13^{\circ} \mathrm{C}$ and $32.83 \mathrm{ppt}$ respectively. Range level of current velocity was 0.05-0,53 $\mathrm{m} \mathrm{dt}^{-1}$ and type of bottom substrat was dominated by fine sa: ds and silt.

KEYWORD: macrozoobenthos, structure community, species composition, diversity indexes, waters quality, sediment, Malaka Strait

\section{FEINLAHULUAN}

Perairan pantai timur Propinsi Sumatera Utara merupakan bagian perairan Selat Malaka dengan potensi sumber daya perikanan laut yang sangat penting. Produksinya telah memberikan kontribusi cukup besar bagi pembangunan sektor perikanan daerah terutama sejak pertama kali diintroduksikan alat tangkap jaring trawl pada tahun 1964 (Unar, 1972). Di lain pihak perairan laut berpotensi mendapatkan tekanan ekologis yang sangat berat terutama bersumber dari bahan buangan maupun pelumpuran (siltasi) yang terbawa aliran Sungai Asahan dan anak-anak sungainya yang banyak bermuara di perairan Selat Malaka; padatnya jumlah alat tangkap trawl yang beroperasi di dasar perairan setiap hari dipastikan merusak struktur sedimen dasar dan pencemaran minyak dari kapal-kapal yang lalu lalang melintas di perairan ini setiap harinya. Faktorfaktor tersebut diduga akan menyebabkan turunnya kualitas perairan dan pada giliran berikutnya akan mempengaruhi kelimpahan sumber daya perikanan.

Salah satu metode analitik untuk mendapatkan informasi kualitas perairan yang erat kaitannya dengan keberadaan populasi ikan demersal adalah dengan menganalisis struktur komunitas organisme bentos, yaitu hewan avertebrata yang mempunyai sifat hidup menetap di dasar perairan serta mempunyai fungsi ekologis sangat penting (Welch, 1952). Beberapa karakter komunitas bentos oleh pakar ekologi sering digunakan dalam menganalisis lingkungan perairan untuk menilai kualitasnya (Wilhelm, 1975; Wilhelm \& Doris, 1968). Penilaian secara biologi tersebut menurut Langford \& Howells (1977) dan Micha \& Kaiser (1977) lebih representatif

\footnotetext{
.) Peneliti pada Balai Riset Perikanan Laut, Jakarta

Teknisi Litkayasa pada Balai Riset Perikanan Laut, Jakarta
} 
dibanding dengan penilaian secara fisik dan kimia, karena sifat biologi telah mencerminkan sifat fisik maupun kimia perairan. Dalam bidang perikanan, kelimpahan bentos mempunyai kaitan erat dengan populasi ikan demersal karena organisme ini termasuk makanan alami yang cukup penting bagi ikan-ikan tersebut, oleh karena itu ukuran kelimpahan populasinya seringkali dijadikan sebagai data dasar oleh pakar perikanan untuk mendukung penelitian pendugaan biomass ikan demersal di suatu perairan (Nybaken, 1988).

Mengingat perairan pantai timur Propinsi Sumatera Utara merupakan daerah tangkapan ikan demersal (fishing ground) cukup penting di kawasan Selat Malaka, sementara di sisi lain degradasi lingkungan diduga berlangsung terus, maka pengkajian tentang kualitas perairan di daerah ini sangat diperlukan. Dalam makalah ini akan diinformasikan hasil penelitian bentos di perairan pantai timur Propinsi Sumatera Utara dengan tujuan mengetahui karakter struktur komunitas bentos yang meliputi komposisi jenis, kelimpahan, dan keragaman jenis makrozoobentos serta beberapa faktor lingkungan. Diharapkan informasi ini dapat memberi gambaran kualitas perairan berdasarkan indikator makrozoobentos sehingga dapat digunakan sebagai salah satu data dukung dalam rangka pengelolaan dan pemanfaatan sumber daya perikanan demersal khususnya di Propinsi Sumatera Utara maupun di perairan Selat Malaka pada umumnya.

\section{BAHAN DAN METODE}

Penelitian dilakukan pada bulan September 2003 dengan menggunakan wahana Kapal Riset Sardinela (68 GT) yang berlokasi di sekitar pantai timur Propinsi Sumatera Utara, kawasan perairan Selat Malaka. Lokasi pengambilan sampel berada pada kisaran kedalaman 21-67 meter terdiri atas 12 stasiun pengamatan dengan posisi geografis seperti pada Gambar 1. Pengambilan sampel dilakukan pada siang hari, contoh bentos dan sedimen dasar diambil dengan menggunakan grab bottom sampler ukuran $20 \times 20 \mathrm{~cm}$. Pada tiap stasiun pengamatan, pengambilan sampel dilakukan sebanyak 3 kali. Organisme bentos yang diamati adalah kelompok makrozoobentos yang diperoleh dengan menyaring sampel substrat, menggunakan ayakan bertingkat dengan ukuran bukaan (mess size) 1,0 mm; 1,5 mm; dan $2.0 \mathrm{~mm}$. Sampel bentos yang diperoleh diawetkan dalam larutan alkohol $70 \%$, selanjutnya diidentifikasi berdasarkan genus dan dihitung kepadatannya dalam satuan individu $\mathrm{m}^{-2}$. Identifikasi genus bentos menggunakan referensi Tan \& Peter (1988); Zin \& Ingle (1995); Habe \& Kosuge (1966); dan Abbot \& Dance (1982).

Kondisi fisik (tekstur) substrat diamati secara deskriptif dengan memperhatikan komposisi tekstur yang dominan, sedangkan parameter kualitas air di sekitar dasar perairan yang diamati meliputi: kecerahan air, kedalaman, suhu, salinitas, dan arus,

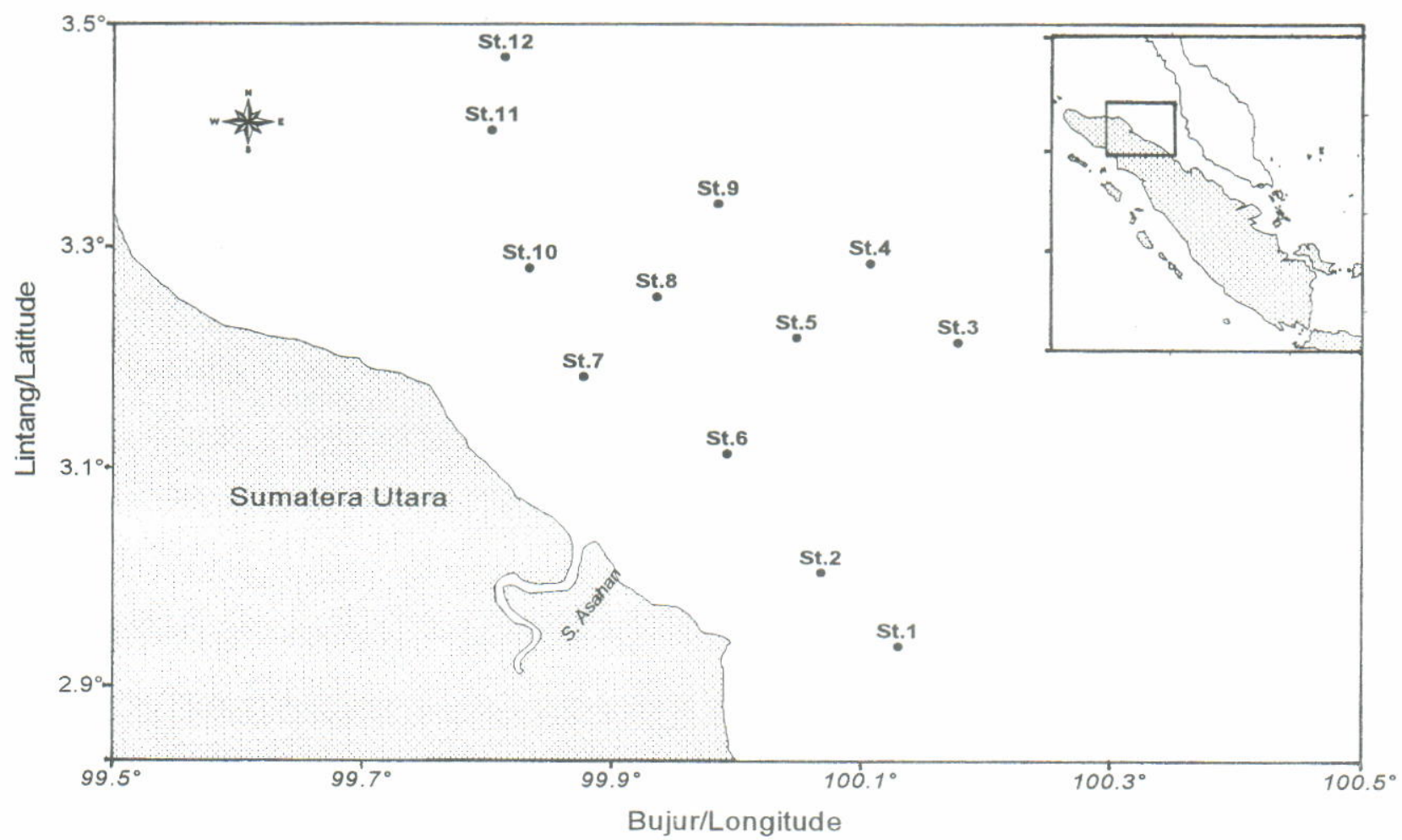

Gambar 1. Peta lokasi stasiun penelitian di perairan Sumatera Utara (Selat Malaka) bulan September 2003. Figure 1. Map of the sampling station position in Sumatera Utara waters (Malaka Strait) at September 2003. 
berturut-turut menggunakan sechi disk dan CTDCurrent Meter Valeport tipe 308.

Analisis data struktur komunitas bentos ditujukan untuk memperoleh komposisi jenis, kepadatan, dan beberapa indeks keragaman hayati menurut Ludwig \& Reynold (1988) meliputi:

1) Indeks kekayaan jenis (Richness indexes) menggunakan persamaan:

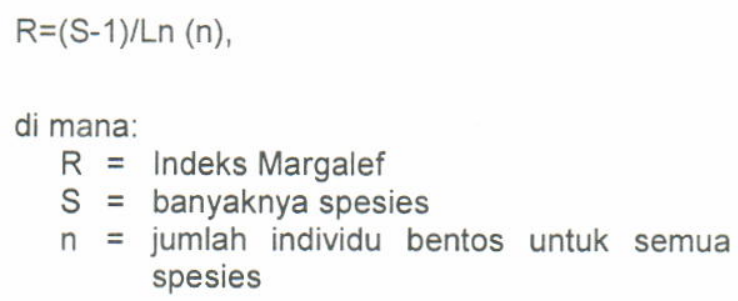
spesies

2) Indeks keanekaragaman jenis (Diversity indexes) dengan persamaan:

$$
\begin{aligned}
& H^{\prime}=-\Sigma(n i / n) \operatorname{Ln}(n i / n) \\
& \lambda=\Sigma \mathrm{ni}(\mathrm{ni}-1) / \mathrm{n}(\mathrm{n}-1)
\end{aligned}
$$

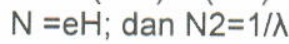

$$
\begin{aligned}
& \text { di mana: }
\end{aligned}
$$

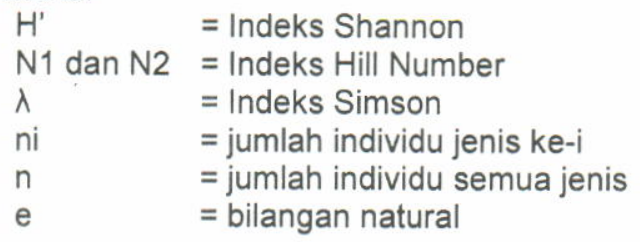

3) Indeks kemerataan (Evenness indexes), dengan persamaan:

$$
E 1=\left(H^{\prime} / \operatorname{Ln} S\right)
$$

di mana:

$$
\begin{aligned}
& \mathrm{E} 1=\text { Indeks Pielou } \\
& \mathrm{H}^{\prime}=\text { Indeks keanekaragaman } \\
& \mathrm{S}=\text { banyaknya spesies }
\end{aligned}
$$

\section{HASIL DAN BAHASAN}

\section{Kondisi Lingkungan Dasar}

Hasil analisis kualitas perairan di sekitar dasar tercantum pada Tabel 1. Lokasi pengambilan sampel berada pada kisaran kedalaman 21-67 m, kecerahan air umumnya kurang dari $10 \mathrm{~m}$, dengan kisaran 3,2$11,9 \mathrm{~m}$.

Kondisi suhu air di lapisan dasar pada setiap stasiun variasinya tidak begitu lebar, berkisar 29,05$29,20^{\circ} \mathrm{C}$, rata-rata $29,13^{\circ} \mathrm{C}$. Suhu relatif tinggi umummya cenderung menempati lokasi stasiun sekitar perairan mendekati pantai (stasiun 1, 2, 8, 7 , dan 10), sebaliknya relatif rendah pada wilayah bagian tengah jauh dari pantai (stasiun 3, 4, dan 5). Demikian pula variasi kondisi salinitas antar stasiun tampak merata (rata-rata $32,83 \%$ ), berkisar antara $32,70-32,97 \%$. Di sekitar pantai salinitas relatif rendah, sebaliknya salinitas relatif tinggi ditemukan dipertengahan perairan. Kecepatan arus relatif rendah, rata-rata $0,37 \mathrm{~m} \mathrm{dt}^{-1}$ dengan kisaran $0,05-$ $0,53 \mathrm{~m} \mathrm{dt}^{-1}$. Tipe sedimen dasar sebagian besar terdiri atas pasir halus dan campuran pasir berlumpur.

Tabel 1. Kondisi kualitas perairan dasar di perairan Sumatera Utara (Selat Malaka), bulan September 2003

Table 1. The condition of bottom water quality in Sumatera Utara Waters (Malaka Strait) on September 2003

\begin{tabular}{ccccccl}
\hline $\begin{array}{c}\text { Stasiun/ } \\
\text { Station }\end{array}$ & $\begin{array}{c}\text { Dalam/ } \\
\text { Depth } \\
(\mathbf{m})\end{array}$ & $\begin{array}{c}\text { Kecerahan }(\mathbf{m}) / \\
\text { Transparency }\end{array}$ & $\begin{array}{c}\text { Suhu }\left({ }^{\circ} \mathbf{C}\right) / \\
\text { Temperature }\end{array}$ & $\begin{array}{c}\text { Salinitas/ } \\
\text { Salinity(\%) }\end{array}$ & $\begin{array}{c}\text { Kec.Arus/ } \\
\text { Current } \\
\left(\mathbf{m ~ d t}^{-1}\right)\end{array}$ & $\begin{array}{c}\text { Sedimen } \\
\text { (sediment) }\end{array}$ \\
\hline 1 & 36 & 8 & 29,15 & 32,71 & 0,05 & Lumpur/silt \\
2 & 42 & 3,2 & 29,14 & 32,76 & 0,24 & Pasir halus/fine sands \\
3 & 63 & 9 & 29,06 & 32,96 & 0,17 & Pasir halus/fine sands \\
4 & 67 & 10 & 29,05 & 32,97 & 0,17 & Pasir halus/fine sands \\
5 & 47 & 11,9 & 29,08 & 32,91 & 0,28 & Pasir berlumpur/fine sands \\
6 & 46 & 6 & 29,16 & 32,75 & 0,50 & Pasir berlumpur/fine sands \\
7 & 21 & 4,2 & 29,2 & 32,70 & 0,23 & Lumpur/silt \\
8 & 40 & 7,2 & 29,16 & 32,83 & 0,45 & Pasir halus/fine sands \\
9 & 58 & - & 29,15 & 32,88 & 0,49 & Pasir halus/fine sands \\
10 & 46 & 4,8 & 29,15 & 32,76 & 0,34 & Pasir berlumpur/fine sands \\
11 & 48 & 7 & 29,17 & 32,79 & 0,38 & Lumpur/silt \\
12 & 56 & 9 & 29,16 & 32,80 & 0,50 & Pasir berlumpur/fine sands \\
\hline
\end{tabular}


Memperhatikan dominasi sedimen yang membentuk dasar perairan, tampak bahwa perairan ini tipe sedimennya banyak dipengaruhi oleh aliran sungai. Menurut Odum (1971); Davies (1980); Krumbein \& Sloss (1963), sedimen dasar perairan biasanya berasal dari aliran sungai yang membawa partikel-partikel lumpur kemudian mengendap di dasar perairan laut membentuk tipe sedimen tertentu. Tipe sedimen ditentukan oleh kekuatan ombak dan arus di laut, bila arus kuat maka partikel-partikel yang mengendap ukurannya relatif lebih besar, keadaan sebaliknya bila kondisi arus lemah. Hasil pengukuran arus di lokasi penelitian menunjukkan kecepatan yang relatif lemah, rata-rata $0,37 \mathrm{~m} \mathrm{dt}^{-1}$, sedangkan tekstur yang diamati mempunyai ukuran butiran relatif halus. Dengan demikian dapat dikatakan bahwa di perairan ini telah terjadi pengendapan lumpur dan pasir halus yang diduga berasal dari sungai-sungai yang bermuara di sekitar perairan Selat Malaka.

\section{Komposisi Makrozoobentos}

Hasil identifikasi terhadap makrozoobentos dari seluruh stasiun pengamatan ditemukan sebanyak 36 genus makrozoobentos yang tergolong dalam 4 filum yaitu Mollusca, Annelida, Arthropoda, dan Echinodermata (Tabel 2). Kelompok Moluska menunjukkan jumlah genus relatif dominan yakni terdiri atas 15 genus dari klas Bivalvia, 15 genus dari klas Gastropoda, dan 1 genus dari klas Scaphopoda. Filum lainnya masing-masing terdiri atas satu klas dan hanya beranggota 1-3 genus. Genus Dentallium sp., Turritella sp., Plicarcularia sp., Polinices sp., dan Ancilla sp. tampak menempati pada hampir seluruh stasiun, demikian pula Tellina sp., dan Epicodakia sp. (Klas Bivalvia). Indikasi tersebut menunjukkan bahwa makrozoobentos tersebut mempunyai penyebaran paling luas. Sebaliknya yang memperlihatkan sebaran realtif sempit adalah Peplum sp., Vasticardium sp., Phacosoma sp., Chlamys sp., Samarangia sp., Marmorostoma sp. (Klas Bivalvia), Errosaria, Natica sp., Calpurnus sp., Cymbiolista sp., Mitra sp., Teramachia sp., Architectonika sp. (Klas Gastropoda), dan Hyperia sp. (Klas Malacostraca, Fillum Arthropoda).

Hasil evaluasi jumlah genus setiap stasiun menunjukkan nilai yang bervariasi dengan kisaran 326 jenis. Jumlah jenis tertinggi ditemukan pada stasiun 6,4 , dan 12 sebaliknya jumlah relatif sedikit pada stasiun 1, 7, dan 10 (Gambar 2).

\section{Kepadatan}

Kepadatan individu pada setiap stasiun juga menunjukkan nilai bervariasi yakni berkisar $3,8 \times 10^{3}-7,1 \times 10^{5}$ ind $\mathrm{m}^{-2}$. Kepadatan tertinggi pada stasiun 5,6 , dan 4 , sebaliknya terendah pada stasiun 7 dan 1 (Gambar3).

Dua komponen (jumlah jenis dan kepadatan) seperti telah diuraikan, menegaskan tentang kekayaan jenis bentos di perairan ini dan sebaran kelimpahan individu tersebut di antara spesiesspesies, keduanya tampak memperlihatkan pola diagram hampir serupa yakni pada stasiun-stasiun yang mempunyai kelimpahan jenis tinggi cenderung diikuti oleh kepadatan yang tinggi pula. Menurut Ludwig \& Reynold (1988) gabungan informasi keduanya di dalam komunitas merupakan indeks keanekaragaman yang sangat penting dalam ekologi.

Hasi! perhitungan indeks keragaman komunitas bentos pada stasiun pengamatan di perairan pantai timur Sumatera Utara (Selat Malaka) tercantum pada Tabel 3

Tampak bahwa stasiun 6, 4, dan 12 memperlihatkan nilai indeks keragaman jenis Shannon $\left(H^{\prime}\right)$ tinggi, indeks Simpson $(\lambda)$ rendah, N1 dan N2 tinggi, kekayaan jenis (R) tinggi, dan indeks kemerataannya cenderung mendekati satu. Keadaan sebaliknya tampak terjadi pada stasiun 1 dan 7 . Indikasi tersebut menunjukkan bahwa pada stasiun 6 , 4, dan 12 mempunyai keragaman dan kekayaan jenis makrozoobentos tertinggi dengan tingkat kelimpahan relatif dari spesies-spesies tersebut sebarannya cenderung merata. Keadaan sebaliknya nilai yang paling rendah ditemukan pada stasiun 1 dan 7 .

Menurut Fresi et al., (1983) tipe sedimen sangat menentukan dinamika populasi organisme dasar (bentos), baik terhadap parameter struktural (komposisi dan keanekaragaman) maupun terhadap parameter fungsional termasuk biomassnya. Bila diperhatikan hasil analisis beberapa faktor lingkungan dasar perairan (Tabel 3), tampak bahwa indeks keanekaragaman jenis makrozoobentos pada stasiun 1 dan 7 yang memperlihatkan nilai rendah cenderung mempunyai tipe substrat terdiri lumpur, sebaliknya nilai indeks keanekaragaman tinggi pada stasiun 6,4 , dan 12 lingkungannya cenderung bertipe substrat pasir halus. Sementara itu, kondisi parameter lingkungan lainnya tampak tidak bervariasi dan hampir merata di semua stasiun (Tabel 3).

Bila diperhatikan secara keseluruhan, maka secara umum lokasi perairan pantai timur Sumatera Utara memiliki rata-rata indeks keragaman jenis bentos relatif rendah yaitu indeks $H^{\prime}=1,77$ (Tabel 3) dan bila mengacu kriteria Lee et al., (1978), perairan ini termasuk kategori tercemar ringan. Indeks keragaman makrozoobentos di daerah ini memperlihatkan kondisi yang hampir serupa dibanding perairan lain seperti di Teluk Jakarta (Afandi, 2002). Namun, tampaknya kualitas perairan di kawasan perairan Selat Malaka berdasar indeks keragaman makrozoobentos tidak semuanya rendah, ada lokasi tertentu yang memperlihatkan nilai masih tinggi seperti di sekitar Pulau Jemur Propinsi Riau (Anonimous 2002).

Indeks kemerataan Pielou (E1) diperoleh nilai ratarata mendekati satu $(0,77)$, menunjukkan bahwa secara intuisi, kelimpahan relatif dari spesies-spesies 
Tabel 2. Komposisi jenis makrozoobentos (ind $\mathrm{m}^{-2}$ ) di perairan Sumatera Utara (Selat Malaka), bulan

Table 2. Species composition of macrozoobentos (ind $\mathrm{m}^{-2}$ ) in Suametra Utara waters (Malaka Strait) on September 2003

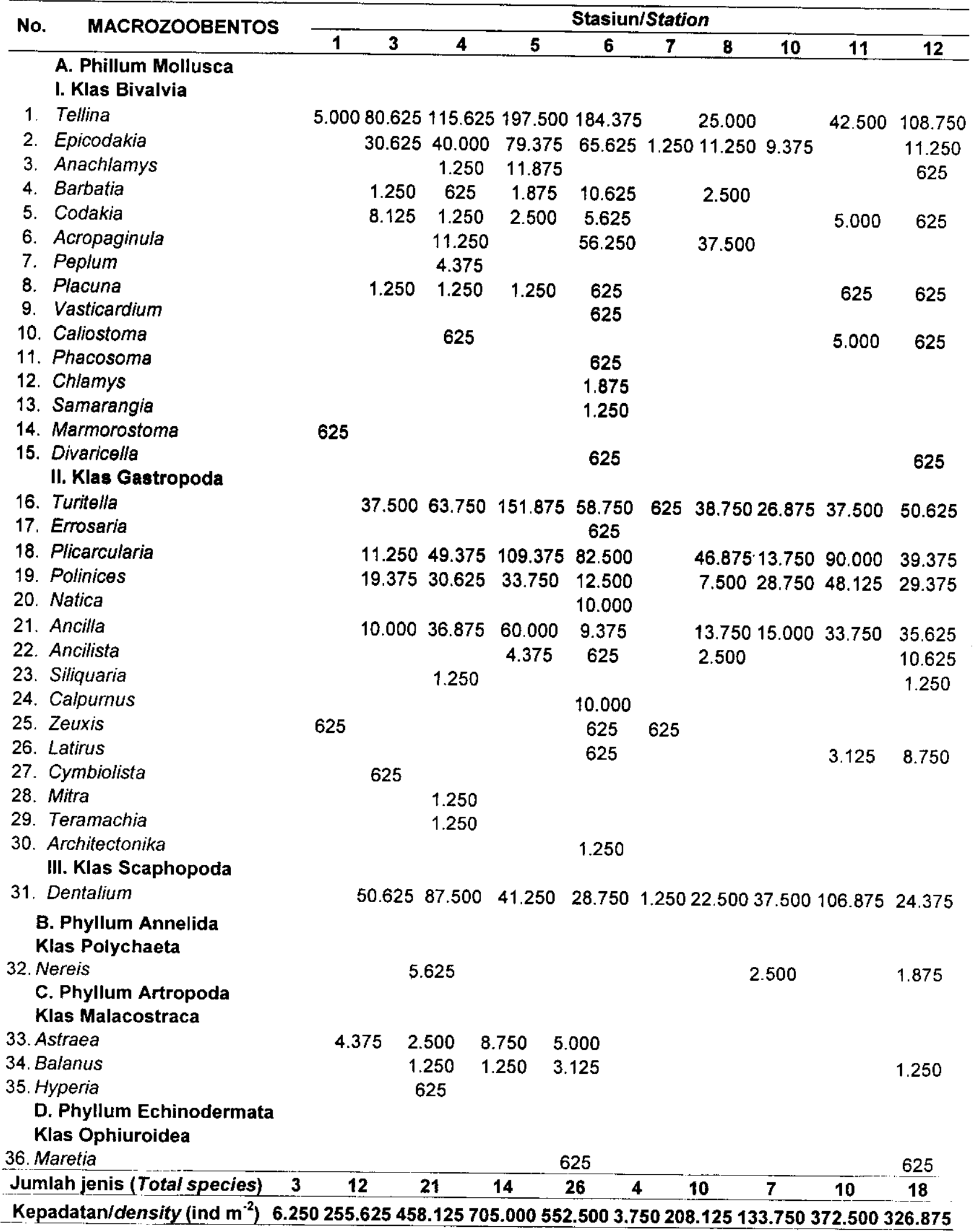




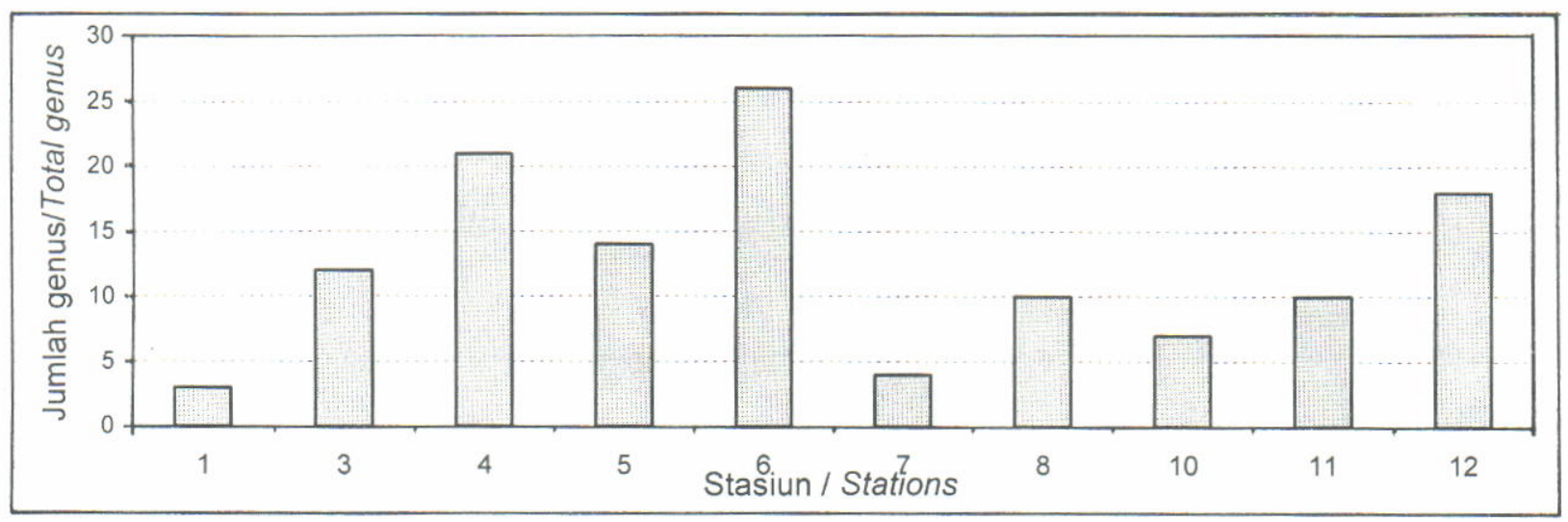

Gambar 2. Variasi jumlah genera makrozoobentos di perairan Sumatera Utara (Selat Malaka) bulan September 2003.

Figure 2. Number the variation of macrozoobentos genera at Sumatera Utara (Malaka Strait) Waters at September 2003.

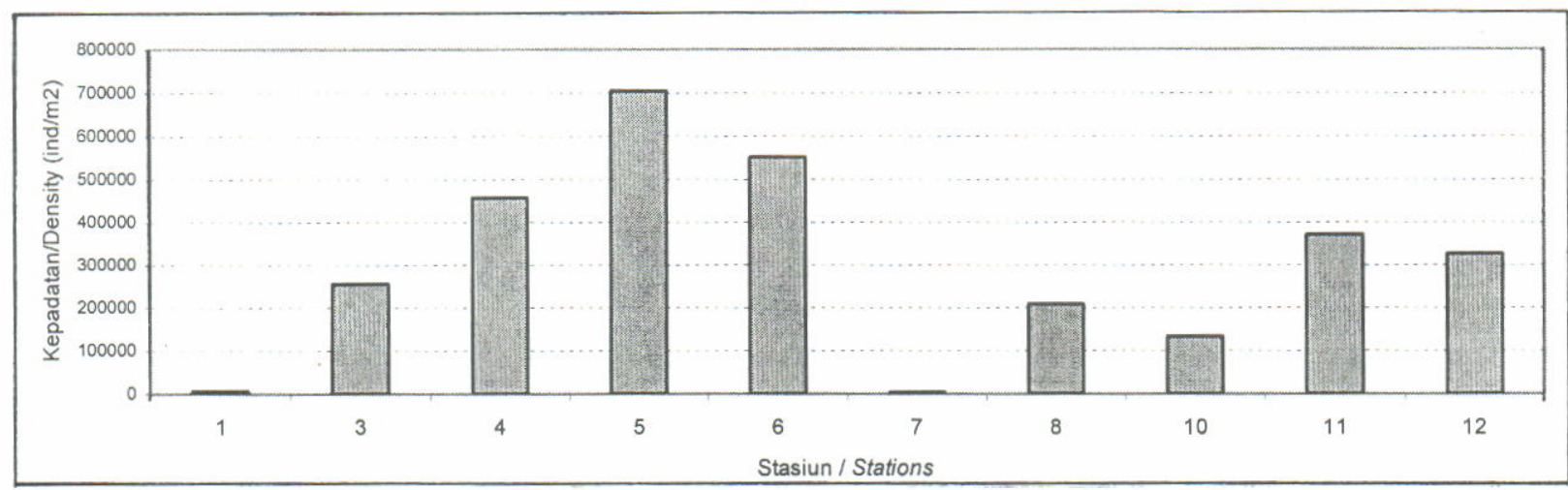

Gambar 3. Variasi kepadatan makrozoobentos pada stasiun pengamatan di perairan Sumatera Utara (Selat Malaka), bulan September 2003.

Figure 3. Variation of macrozoobenthos density in Sumatera Utara (Malaka Strait) Waters on September 2003.

Tabel 3. Daftar indeks keragaman makrozoobentos pada stasiun pengamatan di perairan Sumatera Utara (Selat Malaka), bulan September 2003

Table 3. Diversity indexes of macrozoobenthos at Sumatera Utara Waters (Malaka Strait) Waters on September 2003

\begin{tabular}{ccccccccc}
\hline Stasiun/Station & $\mathbf{S}$ & $\mathbf{n}$ & $\mathbf{H}^{\prime}$ & $\mathbf{A}$ & $\mathbf{N 1}$ & $\mathbf{N 2}$ & $\mathbf{R}$ & $\mathbf{E} 1$ \\
\hline 1 & 3 & 250 & 0,64 & 0,66 & 1,89 & 1,52 & 0,36 & 0,58 \\
3 & 12 & 10.225 & 1,93 & 0,19 & 6,86 & 5,40 & 1,19 & 0,78 \\
4 & 21 & 18.325 & 2,13 & 0,15 & 8,44 & 6,64 & 2,04 & 0,70 \\
5 & 14 & 28.200 & 1,96 & 0,18 & 7,07 & 5,71 & 1,27 & 0,74 \\
6 & 26 & 22.100 & 2,14 & 0,17 & 8,49 & 5,74 & 2,50 & 0,66 \\
7 & 4 & 150 & 1,33 & 0,27 & 3,78 & 3,66 & 0,60 & 0,96 \\
8 & 10 & 8.325 & 2,02 & 0,15 & 7,51 & 6,55 & 1,00 & 0,88 \\
10 & 7 & 5.350 & 1,75 & 0,19 & 5,75 & 5,17 & 0,70 & 0,90 \\
11 & 10 & 14.900 & 1,83 & 0,19 & 6,23 & 5,29 & 0,94 & 0,79 \\
12 & 18 & 13.075 & 2,03 & 0,18 & 7,61 & 5,63 & 1,79 & 0,70 \\
\hline Rata-rata (Average) & & & $\mathbf{1 , 7 7}$ & $\mathbf{0 , 2 3}$ & $\mathbf{6 , 3 6}$ & $\mathbf{5 , 1 3}$ & $\mathbf{1 , 2 4}$ & $\mathbf{0 , 7 7}$ \\
\hline Keta
\end{tabular}

\begin{tabular}{ll} 
Rata-rata (Average) & $\mathbf{1 , 7 7}$ \\
\hline Keterangan/Note: & = Jumlah genus/Total species \\
$\mathrm{S}$ & $=$ Jumlah individu/Total individu \\
$\mathrm{n}$ & $=$ Indeks Keanekaragaman/Diversity index Shannon \\
$\mathrm{H}^{\prime}$ & $=$ Indeks Simpson/Simpson index \\
$\hat{A}$ & $=$ Nomor indeks keragaman/Hill diversity number \\
$\mathrm{N} 1-\mathrm{N} 2$ & $=$ Indeks kemerataan/Evenness index Pielou \\
$\mathrm{E} 1$ & $=$ Indeks kekayaan jenis (Richness index) \\
$\mathrm{R} 1$ &
\end{tabular}


tersebut keberadaannya menyebar rata di perairan pantai timur Sumatera Utara. Terhadap indeks keragaman N1 dan N2 diperoleh rata-rata 6,36 dan 5,13 dapat diartikan bahwa di perairan pantai timur Sumatera Utara ditemukan sekitar 6 spesies yang melimpah, antara lain Tellina sp., Epicodakia sp., Dentalium sp., Turitella sp., Plicarcularia sp., dan Ancilla sp. Sedangkan dari sejumlah spesies tersebut diketahui 5 di antaranya termasuk spesies yang paling melimpah, kecuali Ancilla sp.

\section{KESIMPULAN}

1. Keanekaragaman jenis makrozoobentos di perairan pantai timur Sumatera Utara (Selat Malaka) relatif rendah yaitu $H^{\prime}=1,77$ dan bila mengacu kriteria Lee et al., (1978), perairan ini termasuk kategori perairan telah tercemar ringan. Makrozoobentos teridentifikasi sekitar 36 genus dan sebagian besar didominasi oleh filum Moluska yang terdiri atas klas Bivalva, Gastropoda, dan Scaphopoda, sedangkan filum lainnya relatif sedikit tergolong dalam Annelida, Arthropoda, dan Echinodermata. Kepadatan makrozoobentos berkisar antara $3,8 \times 10^{3}-7,1 \times 10^{5}$ ind $\mathrm{m}^{-2}$ dengan kelimpahan relatif di antara jenisjenis tersebut cenderung menyebar merata di seluruh perairan. Jenis makrozoobentos yang paling melimpah dan menyebar luas adalah Tellina sp., Epicodakia sp., Dentalium sp., Turitella sp., Plicarcularia sp. Indeks keanekaragaman jenis makrozoobentos memperlihatkan nilai rendah cenderung berada pada lokasi yang mempunyai tipe substrat terdiri lumpur, sebaliknya nilai indeks keanekaragaman tinggi pada lingkungan substrat dasar terdiri atas pasir halus.

2. Kondisi suhu dan salinitas di lingkungan perairan dasar tidak bervariasi, rata-rata $29,13^{\circ} \mathrm{C}$ dan $32,83 \%$. Kecepatan arus umumnya lemah berkisar 0,05-0,53 m dt $\mathrm{mt}^{-1}$, sedangkan substrat dasar didominasi campuran pasir berlumpur.

\section{DAFTAR PUSTAKA}

Afandi, H. 2002. Kelimpahan makrozoobentos sebagai parameter kualitas air di perairan Laut Teluk Jakarta. Laporan Kerja Lapangan, Fakultas Biologi Universitas Jenderal Soedirman, Purwokerto. $34 \mathrm{~h}$.

Anonimous. 2002. Inventarisasi karakteristik potensi perikanan Pulau Jemur untuk pengembangan usaha perikanan. Dinas Perikanan Laut Propinsi Riau-PKSPL Universitas Riau. $47 \mathrm{~h}$.

Abbort, R. T. \& Dance, S. P. 1982. Compendium of sea shells, a full colour guide to more than 4200 of the world marine shells. E. P.Duta Inc., New York. $410 \mathrm{pp}$.

Davies, J. L. 1980. Geographical variation in coastal development. Lowe \& Brydone Printers Limited. The Ford, Nort Folk: 212 pp.
Fresi, E., M. C. Gambi, S. Focardi, R. Barbgagli, F. Baldi, \& L.Falcial. 1983. Benthic community and sediment types: a structural analysis. Mar. Ecol. 4(2): 101-121.

Habe, T. \& Kosuge, S., 1966. Shells of the world in colour. Vol.II "The Tropical Pacific". Hoikhusha, Tokyo, $193 \mathrm{pp}$.

Krumbein, W. C. \& L. L. Sloss. 1963. Stratigraphy and sedimentation. M.H. Freemen and Company, San Fransisco: 460 pp.

Langford, T. E \& G. Howells. 1977. The Use of biological monitoring in the freshwater environment by the electrical industry in the UK in Alabaster, J. S. (eds). 1977. Biological Monitoring of Inland Fisheries, Applied Science Publishers Ltd., London: 115-122 pp.

Ludwig, J. A. \& J. F. Reynold. 1988. Statictic ecology. A primer on methods and computing. John Wiley \& Sons, New York, 337 pp.

Lee, C. D., S. B. Wang \& C. L. Kuo. 1978. Benthic macro invertebrate and fish as biological indicators of water quality with reference to community diversity index. in water pollution control in developing countries. Rhe Asian Institute of Technoloy, Bangkok: 233-238 p.

Micha,J. C. \& R. Kaiser. 1977. Pollution and the production of invertebrates and fish in canalized river. In Alabaster,J. S (ed.) 1977. Biological Monitoring of Inland Fisheries, Applied Science Publishers Ltd., London: 107-114 pp.

Nybaken,J.W., 1988. Biologi laut: suatu pendekatan ekologis, Alih Bahasa H.M.Eidman et al, cet. 1, Gramedia, Jakarta, 480 hal.

Odum, E. P. 1971. Fundamental of Ecology. $3^{\text {rd }}$ Edition, W. B. Sounders Comp., Phildelphia. 574 hal.

Tan, L. W. H \& Peter K. L. 1988. A guide to seashore science centre. Singapore. $159 \mathrm{pp}$.

Unar, M. 1972. Selat Malaka ditinjau dari segi perikanannya. Lembaga Penelitian Perikanan Laut. Jakarta. 26 pp.

Welch, P. S. 1952. Limnology. $2^{\text {nd }}$, Mc.Graw-Hill Book Company Inc., New York (XI): 538 pp.

Wilhelm, J. L. 1975. Biological indicator of pollution, in Whitton (ed.), 1975. River Ecology, Blacwell Scientific Publication, London: 375-402.

Wilhelm, J. L. \& T. C. Dorris. 1968. Biological parameters for water quality criteria. Bioscience. Vol.18: 477-480

Zim, H. S \& Ingle, L. 1955. A golden guide: sea shores, a guide to animals and plants a long the beaches. Golden Press, New York, 160 pp. 
